\title{
Pengembangan Rubrik Berpikir Kreatif Siswa Menengah Atas dalam MenYelesaikan MaSalah Matematika
}

\section{Development of Rubric Creativity Thinking Skill Senior High School in Mathematical Problem Solving}

\author{
Silvia Fitriani1 ${ }^{\text {dan }}$ Ayu Yarmayani² \\ 1Universitas Batanghari Jambi \\ Jl. Slamet Riyadi No.01, Sungai Putri, Telanaipura, Jambi, Indonesia \\ Silviafitriani1089@yahoo.com \\ 2Universitas Batanghari Jambi \\ Jl. Slamet Riyadi No.01, Sungai Putri, Telanaipura, Jambi, Indonesia
}

\begin{abstract}
Abstrak
Tujuan penelitian ini adalah untuk mengetahui karakteristik produk pengembangan rubrik keterampilan berpikir kreatif siswa dalam pemecahan masalah matematika pada materi program linier dan mengetahui Kelayakan rubrik ketrampilan berfikir kreatif siswa dalam pemecahan masalah matematika, melalui penilaian guru matematika SMA sebagai pengguna dan pertimbangan validasi (ahli). Jenis penelitian yang digunakan dalam penelitian ini adalah penelitian pengembangan dan model pengembangan yang digunakan yaitu 4D, model pengembangan ini terdiri dari 4 tahap sesuai dengan namanya, yaitu define (pendefinisian), design (perancangan), develop (pengembangan), dan disseminate (penyebaran). Karena keterbatasan waktu maka penelitian hanya dilakukan sampai pada tahap develop (pengembangan). Berdasarkan penilaian dari validator dan guru, instrumen yang dikembangkan sudah layak dan dapat diterapkan untuk siswa kelas XI IPA.

Kata Kunci: rubric, berpikir kreatif, pemecahan masalah.
\end{abstract}

\begin{abstract}
The purpose of this research was to knew the characteristics of the product development of creative thinking skills rubric students in mathematical problem solving in the subject matter of program linier in the Senior High School City of Jambi and knew the eligibility section of creative thinking skills of students in mathematical problem solving, through consideration of assessment junior high school math teacher as a user and validation (expert). This type of research used in this study is the development of research and development model used is $4 D$, this development model consists of four stages in accordance with its name, define (definition), design (design), develop (development), and disseminate (spread). because of limited time the research only done until development step. Based on the assesment from the validator and the teacher, the instrument which development had been and can to be apply for students on Senior high school of eight grade in the class.

Keyword: rubric, creative thinking, mathematical problem solving.
\end{abstract}




\section{Pendahuluan}

Berpikir kreatif merupakan aktivitas berpikir untuk mengembangkan atau menemukan ide atau hasil yang asli (orisinil), estetis, konstruktif yang berhubungan dengan pandangan, konsep, yang penekanannya ada pada aspek berpikir intuitif dan rasional khususnya dalam menggunakan informasi (Rofiah.E, Aminah. N. S, \& Ekawati. E. Y, 2013; Ismaimuza, 2013).

Upaya mengoptimalisasikan berpikir kreatif siswa maka mengintegrasikan kedalam mata pelajaran khususnya mata pelajaran matematikan sangat penting.

Matematika merupakan salah satu mata pelajaran yang diberikan kepada semua peserta didik mulai dari sekolah dasar sampai perguruan tinggi untuk membekali peserta didik dengan kemampuan berpikir logis, analitis, sistematis, kritis dan kreatif serta kemampuan bekerjasama. Siswa harus dididik untuk kreatif agar tidak hanya menjadi konsumen pengetahuan tetapi juga mampu menghasilkan pengetahuan baru. Untuk itu dituntut peran pendidik dalam menyiapkan materi, mengolah proses pembelajaran dan menilai kompetensi yang dimiliki siswa sesuai tuntutan kurikulum. Dalam penyelesaian masalah matematika, siswa melakukan proses berpikir kreatif untuk merancang langkah-langkah sehingga siswa dapat sampai pada jawaban. Kemampuan pemecahan masalah adalah merupakan tujuan umum dan kemampuan dasar dalam pembelajaran matematika.
Pembelajaran pemecahan masalah matematika merupakan salah satu cara

untuk mendorong kreativitas sebagai proses berpikir. Dengan demikian, pemecahan masalah memiliki peran penting dan inti dalam pembelajaran matematika. Mulai dari pendidikan dasar, pendidikan menengah sampai perguruan tinggi peserta didik belajar matematika (Branca, 2002; Rahayu, 2008).

Hasil observasi yang dilakukan di Sekolah Menengah Atas (SMA) di kota Jambi, peneliti melihat bahwa pada proses pembelajaran terlihat siswa yang sebenarnya memiliki kemampuan bepikir kreatif dalam mengajukan pertanyaan pada guru atau dalam memecahkan masalah. Dalam melakukan penilaian guru hanya melakukan penilaian konvensional saja, sehingga diperlukan suatu instrumen untuk mendeteksi siswa yang memiliki kemampuan berpikir kreatif. Penilaian dalam mengukur kemampuan berfikir kreatif yang memiliki arti penting dalam pelajaran matematika tersebut masih belum dikembangkan oleh guru. Hasil wawancara peneliti dengan beberapa guru Matematika SMA di Kota Jambi, membawa pada kesimpulan bahwa masih banyak guru yang belum terampil dalam mengembangkan instrumen penilaian hasil belajar. Para guru cenderung terbiasa mengembangkan instrumen penilaian hasil belajar dengan bentuk soal objektif atau soal uraian yang biasa digunakan pada kegiatan ulangan dengan teknik tes tertulis. Guru kurang terbiasa mengembangkan instrumen penilaian hasil 
belajar yang digunakan dengan teknik bukan tes tertulis, misalnya tes kinerja atau penugasan proyek. guru juga belum optimal dalam mengembangkan instrumen penilaian hasil belajar yang berorientasi pada pencapaian tujuan mata pelajaran matematika sebagaimana tercantum dalam Permendiknas Nomor 22 tahun 2006 tentang standar isi. Oleh karena itu perlu adanya peningkatan wawasan dan keterampilan mengembangkan instrumen penilaian hasil belajar yang memperhatikan tujuan mata pelajaran matematika yaitu instrumen penilaian hasil belajar untuk mengukur kemahiran matematika, khususnya dalam kemampuan pemahaman konsep, penalaran-komunikasi, pemecahan masalah.

\section{Metode}

Penelitian ini tergolong penelitian pengembangan. Dikatakan penelitian pengembangan karena penelitian ini akan menghasilkan sebuah rancangan baru berupa rubrik kemampuan berfikir kreatif dalam pemecahan masalah matematika sebagai asesmen kinerja, kemudian akan di uji keefektifannya. (Sugiyono, 2012) metode penelitian pengembangan adalah metode penelitian yang digunakan untuk menghasilkan produk tertentu dan menguji keefektifan produk tersebut. Model pengembangan yang digunakan dalam penelitian ini adalah model 4D yang disarankan oleh Thiagarajan, Semmel, dan Semmel (1974) Model pengembangan ini terdiri dari 4 tahap sesuai dengan namanya, yaitu define (pendefinisian), design (perancangan), develop (pengembangan), dan disseminate (penyebaran). Subjek uji coba pada uji coba terbatas adalah siswa kelas XI IPA 1 SMAN 4 Kota Jambi semester 1 tahun ajaran 2017/2018. Subjek uji coba lapangan dilaksanakan di kelas XI IPA 1 SMAN 4 Kota Jambi.

\section{Hasil dan Pembahasan}

Pada tahap analisis awal akhir, dilakukan studi literatur, observasi di SMA Negeri 4 Jambi dan wawancara dengan guru bidang studi matematika. Tahap ini dilakukan untuk memperoleh informasi tentang kondisi sesungguhnya yang terjadi dilapangan. Saat observasi lapangan, peneliti melihat langsung proses pembelajaran matematika di kelas XI SMA Negeri 4 Jambi. Berdasarkan hasil observasi lapangan yang dilakukan, peneliti melihat bahwa pada proses pembelajaran terlihat siswa yang sebenarnya memiliki kemampuan bepikir kreatif dalam mengajukan pertanyaan pada guru atau dalam memecahkan masalah. Dalam melakukan penilaian guru hanya melakukan penilaian konvensional saja, sehingga diperlukan suatu instrumen untuk mendeteksi siswa yang memiliki kemampuan berpikir kreatif. Hasil wawancara dengan guru tersebut menunjukkan bahwa guru belum mengembangkan instrument asesmen kinerja berupa rubrik ketrampilan berfikir kreatif siswa dalam memecahkan masalah matematika. Guru hanya menggunakan 
penilaian tes tertulis yang bersifat global untuk semua materi pelajaran bahkan belum memiliki instrument penilaian pada pelajaran matematika, instrumen penilaian masih bersifat konvensional dari hasil ulangan.

Berdasarkan kenyataan diatas, peneliti bermaksud mengembangkan rubrik ketrampilan berfikir kreatif dalam memecahkan masalah matematika di kelas XI IPA SMA 4 Jambi.

Tahap selanjutnya yang dilakukan oleh peneliti adalah tahap desain pengembangan. Tahap desain ini terdiri dari penentuan jadwal, tim pengembang dan spesifikasi desain instrumen.

Spesifikasi desain instrumen yaitu tahap peneliti membuat produk, dimana produk yang dibuat oleh peneliti berupa instrumen penilaian keterampilan berpikir kreatif yakni berupa lembar observasi dalam bentuk rubrik penilaian. Selanjutnya produk tersebut divalidasi oleh ahli pada tahap pengembangan.

Adapun spesifikasi desain instrumen penilaian keterampilan berpikir kreatif yang dibuat oleh peneliti dengan tiga kriteria penilaian dan rentang skor skala penilaian dari setiap aspek penilaian adalah 1-4.

pada tahap pengembangan yaitu validasi desain dan revisi produk. Pada tahap validasi desain yaitu validasi tim ahli terhadap desain instrument (draft 1) melalui expert judgement (pertimbangan ahli) tentang hasil desain instrumen penilaian keterampilan berpikir kreatif. Instrumen penilaian keterampilan berpikir kreatif divalidasi oleh ahli sebanyak 5 kali. Dari validasi tersebut banyak masukan dan saran dari ahli. Masukan dan saran tersebut disampaikan oleh ahli baik secara lisan melalui diskusi dengan peneliti maupun secara tulisan melalui lembar validasi yang telah dibuat oleh peneliti.

Berdasarkan masukan dan saran dari ahli tersebut maka dilakukan revisi terhadap produk. Revisi produk pertama untuk hasil validasi yang pertama (draft 2) dan revisi produk kedua untuk hasil validasi yang kedua (draft 3). Setelah dilakukan revisi terhadap produk didapat komentar-komentar yang positif dari ahli baik disampaikan secara lisan maupun secara tulisan. Komentar- komentar dari ahli tersebut menyatakan bahwa produk secara teoritis sudah teruji dan layak untuk digunakan.

Validasi selanjutnya adalah validasi yang dilakukan oleh guru sebagai pengguna produk untuk aspek praktikalitas terhadap produk hasil revisi yang kedua (draft 3). Validasi yang dilakukan oleh guru adalah dengan mengisi lembar validasi aspek praktikalitas yang berupa pertanyaan-pertanyaan yang menyangkut penggunaan produk. Validasi untuk aspek praktikalitas ini dilakukan untuk mendapatkan data dari pengguna produk yang dalam hal ini adalah guru mengenai penggunaan produk secara teoritis saja bukan fakta lapangan.

Berdasarkan data yang diperoleh dari lembar validasi secara umum guru menyatakan produk sudah cukup baik dan dapat digunakan dengan syarat-syarat 
tertentu. Terdapat pula saran-saran yang diberikan oleh guru mengenai penggunaan produk, saran tersebut dijadikan masukan oleh peneliti sebagai bahan pertimbangan untuk penelitian selanjutnya. Untuk pengembangan instrumen penilaian keterampilan berpikir kreatif hanya sampai tahap validasi tim ahli dan validasi oleh guru matematika sebagai pengguna produk secara teoritis saja selain validasi juga dilakukan ujicoba instrumen soal secara terbatas kepada 23 orang siswa. Ujicoba tersebut dilakukan untuk mendapatkan data validitas dan reliabilitas.

Berikut adalah hasil pengukuran keterampilan berpikir kreatif siswa di SMA Negeri 4 Jambi:

Tabel 1. Klasifikasi Keterampilan Berpikir Kreatif Siswa

\begin{tabular}{llll}
\hline $\begin{array}{c}\text { Klasifikasi } \\
\text { berpikir } \\
\text { kreatif }\end{array}$ & Interval & $\begin{array}{c}\text { Jumlah } \\
\text { siswa }\end{array}$ & Persentase (\%) \\
\hline Sangat kreatif & $75-96$ & - & $0 \%$ \\
\hline Kreatif & $50-74$ & 9 & $39,13 \%$ \\
\hline $\begin{array}{l}\text { Sedang/cukup } \\
\text { kreatif }\end{array}$ & $25-49$ & 14 & $60,86 \%$ \\
\hline Kurang kreatif & $0-24$ & - & $0 \%$ \\
\hline Jumlah & & 23 & \\
\hline
\end{tabular}

Hasil pengukuran keterampilan berpikir kreatif siswa di SMA Negeri 4 Jambi menunjukkan bahwa sebagian besar siswa memiliki keterampilan berpikir kategori sedang/cukup kreatif yaitu sebanyak 14 siswa atau 60,86\% kategori siswa yang memiliki keterampilan berpikir kreatif sebanyak 9 siswa atau 39,13\%.

\section{Penutup}

Secara garis besar penelitian ini terdiri dari tiga tahap utama yaitu analisis (analysis), desain pengembangan (design) dan pelaksanaan pengembangan (development). Pada akhirnya menghasilkan produk yakni rubrik ketrampilan berpikir kreatif.

Hasil validasi ahli desain dan materi menunjukkan bahwa instrumen keterampilan berpikir kreatif untuk siswa SMA kelas XI IPA layak digunakan. Untuk validasi aspek praktikalitas yang dilakukan oleh guru matematika sebagai validator, sebagian besar memberikan respon yang positif terhadap produk. Komentarkomentar dari guru tersebut berkenaan dengan penggunaan dan manfaat produk. Terdapat dua orang guru yang memberikan saran agar pengembangan instrumen dikembangkan untuk materi matematika yang lain.

Hasil pengukuran keterampilan berpikir kreatif siswa di SMA Negeri 4 Jambi menunjukkan bahwa sebagian besar siswa memiliki keterampilan berpikir kategori sedang/cukup kreatif yaitu sebanyak 14 siswa atau 60,86\% kategori siswa yang memiliki keterampilan berpikir kreatif sebanyak 9 siswa atau 39,13\%.

\section{Daftar Pustaka}

Nitko, A. J., 2001. Educational Assessment of Students Third Edition. New Jersey: Merrill Prentice Hall.

Ormrod, J. E., 2009. Psikologi Pendidikan Membantu Siswa Tumbuh dan Berkembang, edisi-6, Terjemahan Dra. 
Wahyu Indianti, M.Si, Erlangga, Jakarta.

Runco, M. A., 2007. Creativity Theories and

Themes: Research, Development, and Practice. America: Elsevier.

Santrock, J.W., 2008, Psikologi Pendidikan, edisi-2, Terjemahan T.Wibowo, Prenada Media Group, Jakarta.

Silver, Edward A., 1997, Fostering Creativity through Instruction Rich in Mathematical Problem Solving and Thinking in Problem Posing.

Solso, R. L., dkk. 2005. Cognitive Psychology Sevent Edition. New York: Pearson.

\section{Riwayat Hidup PenUlis}

\section{Silvia Fitriani, S.Pd. M.Pd.}

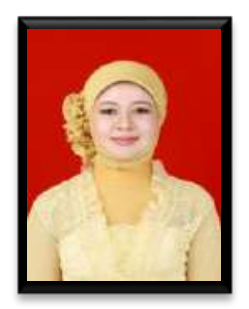

Lahir di Jambi, 10 Mei 1989. Staf pengajar di Universitas Batanghari Jambi Studi S1 Pendidikan Matematika Universitas Jambi, Kota Jambi, lulus tahun 2011; S2 Pendidikan MIPA Universitas tahun 2013. Jambi, Kota Jambi, lulus 